\title{
TRENDS IN THE DEVELOPMENT OF REGIONAL TRUST MANAGEMENT MARKETS
}

\author{
Stanislav Perminov \\ Information Systems Management Institute (ISMA), Riga, Latvia \\ e-mail: psb70@protonmail.com
}

Received: 01 May 2021; $\quad$ Accepted: 20 June 2021; $\quad$ Online Published: 11 August 2021

\begin{abstract}
The article discusses the features of the development of the trust management services market. The purpose of the article is to determine the regional features of the development of the trust management services market. The article uses the methods of quantitative empirical research, statistical analysis and visualization, analysis and assessment of the regional dynamics of the main instruments of trust management. The formation of the trust management market takes into account the peculiarities of the development and economies of individual countries, regional regulatory characteristics. Trust management is widespread in advanced countries, while in other countries this market is just emerging. In general, the trust management market in the countries of Eastern Europe and Russia in particular is only in the process of formation, although the services themselves have a long history of development. They are most often viewed as part of the overall market for banking or insurance services. At the present stage, there is a selection of a separate market segment, determination of the place of trust services in the structure of banking services, identification of regional characteristics in the structure of the global market. The peculiarities of the Russian securities market are: active participation of the state in the processes of market trading, a large number of government securities on the market and a relatively low level of involvement in global processes. The market is relatively small, but its development is quite dynamic. The key prerequisites for the development of the market are: the relative closeness of the market, government regulation, a decrease in the attractiveness of other banking or financial instruments, and an increase in the general welfare of investors.
\end{abstract}

Key words: trust, trust management, assets, unit investment fund, mutual investment fund.

JEL classification: F36, G11, G15, G21

Citation:

Perminov, S. (2021). Trends in the development of regional trust management markets. Access to science, business, innovation in digital economy, ACCESS Press, 2(3): 261-273. https://doi.org/10.46656/access.2021.2.3(5)

\section{INTRODUCTION}

Banking services are an important part of the financial market of any country. Building chains of relationships between financial agents, opportunities for making a profit or serving companies is an integral part of the functioning of the economy as a whole. A special place in the financial services market is occupied by the trust management market, which, in turn, is part of the T\&CS (trust management and corporate services) market. The trust management market is both new and has a long history of development. Trust management as a process and economic activity has its roots in Anglo-Saxon law and is understood as specialized property management in favor of a third party. However, at the present stage of development of the global economy, the formation of the world market for trust management (TM) is already taking place. Trust management in 
modern conditions goes beyond the possibilities of functioning and ensuring the management of property within the framework of individual economies or jurisdictions, representing the formation of a single management system or management capabilities throughout the world. It should be noted that the formation of the trust management market takes into account the peculiarities of the development and economies of individual countries, regional regulatory characteristics and provides for investments in various instruments and assets.

The purpose of the article is to determine the regional features of the development of the trust management services market.

\section{MATERIALS AND METHODS}

The article uses the methods of quantitative empirical research, statistical analysis and visualization, analysis and assessment of the regional dynamics of the main instruments of trust management.

In general, trust and asset management is the subject of research by a large number of scientists, given the complexity of the processes and their regulation, depending on the jurisdiction of implementation. General issues of asset management are explored in the works of I. Smirnov (2020); A. Vorotilov (2013); A. Kovalevich (2012), F. Ripol-Saragossi, E. Ternikova, S. Budylgin; Woodhouse J. (2003); Loistl O. \& Petrag R. (2003), Marinov (2012) and others. We find certain issues of managing specific assets in the works of A. Asaul (Asaul and al, 2007); Labunska, Petrova \& Prokopishyna (Labunska et al, 2017), Puchkina E.S., (2016) and other scientists. Legal regulation of asset management processes is the basis of research by Fedulova D. (2010); Mazajeva A. (Mazajeva, 2017); Radukanov (2012); Milinov (2012), Angelov et al (2012); Petrova \& Radukanov (2021). At the same time, the issues of the formation of the international trust management market and the peculiarities of its regional development deserve special attention.

\section{RESULTS AND DISCUSSION}

The development of the trust services market is based on the following key trends: the level of development of the country, economic stability and stability of financial markets; features and characteristics of the development of the banking and financial systems in the country; peculiarities of the behavior patterns of investors or the population in the country; features and models of regulation of trust activities. Taking into account these and other peculiarities in each country, banks form their own model of relations with clients, allowing them to retain and transfer them to the status of "investors". Thus, a wide network of banking services is being formed, including in the field of trust management.

The main prerequisite for the development of the trust management market in various countries is attracting a class of citizens with an average level of income, which makes it possible to expand and increase the capital attracted for trust management. The middle class of citizens has sufficient potential and financial capabilities to be of interest for trust banking and become a target group for creating demand for this kind of services. 
Thus, the development of the middle class contributes to the development of the financial market in general and the securities market in particular. In turn, this can contribute to the formation and development of the middle class, as well as the growth of savings in this class of citizens. The main problems and constraints on the development of the trust management market can be:

- lack of legislative base, its limitations and "gaps";

- underdevelopment of the stock market in certain countries (especially in developing countries), which may lead to a decrease or insufficient profitability of this kind of activity;

- high volatility of markets and a limited number and possibilities of using financial instruments;

- low level of informing the population about the availability of this type of service;

- shortage of highly qualified financial agents capable of working in the stock market and especially in developing countries.

However, most of the restrictions can be resolved with the active development of the stock market with the participation of the state and regulatory authorities. For developing countries, the prerequisites for the development of the trust management market are:

- the formation of a middle class of citizens, which occurs as a result of the growth of savings and financial savings;

- gradual accumulation of the share of financial assets in the structure of capital and the welfare of citizens;

- the need to implement relatively reliable financial instruments and effective management of these assets;

- a sufficient level of development of the banking system and financial institutions;

- accumulation of experience in the field of trust management;

- formation of a legal framework that regulates the trust management market.

In modern conditions, the formation of an international trust management market is taking place, which goes beyond the jurisdictions of financial management of individual countries. There are several regions that have implementation features and specific characteristics of the development of the trust management market. A certain interest is aroused by the market of the CIS countries, where the trust management market is at the stage of its formation. In general, there is a gradual growth of this market, a feature of which is growth at the expense of deposits of individuals, as well as at the expense of clients with large private investment capital. Thus, the volume of assets only managed by the largest market players grew by almost $5 \%$ only in the 4th quarter of 2020. At the same time, the bottom line of assets in the TOP-15 exceeded 100 billion rubles (Table $1)$.

In general, there is a gradual increase in assets to 7.6 trillion rubles, while the growth in the volume of assets of TOP-5 companies - up to 4.5 trillion rubles $(4.1 \%)$. At the same time, the composition of the leaders is constantly changing, which indicates intense competition in this area. For example, the management company 
Gazprombank - Asset Management has increased its assets by more than 50 billion rubles, which allowed it to enter the TOP-5.

Table 1. Rating of the largest asset management companies by the amount of funds raised, Q4 2020

\begin{tabular}{|c|c|c|c|c|c|c|}
\hline $\begin{array}{l}\text { Ranking, } \\
\text { Q3 2020 }\end{array}$ & $\begin{array}{l}\text { Ranking, } \\
\text { Q2 2020 }\end{array}$ & Management Company & $\begin{array}{l}\text { Rating of } \\
\text { reliability } \\
\text { and } \\
\text { quality of } \\
\text { services }\end{array}$ & $\begin{array}{l}\text { Amount of } \\
\text { funds under } \\
\text { management, } \\
\text { 31.12.2020, } \\
\text { million rubles, }\end{array}$ & $\begin{array}{c}\text { Amount of } \\
\text { funds under } \\
\text { management, } \\
\text { 30.09.2020, } \\
\text { million rubles, }\end{array}$ & $\begin{array}{c}\text { Relative } \\
\text { change for } \\
\text { Q4 2020, } \\
\%\end{array}$ \\
\hline 1 & 1 & $\begin{array}{l}\text { Business company "VTB } \\
\text { Capital } \\
\text { Management" }\end{array}$ & $\mathrm{A}++$ & 1275987 & 1164509 & 9,6 \\
\hline 2 & 2 & $\begin{array}{lr}\text { Business } & \text { company } \\
\text { "Sberbank } & \text { Asset } \\
\text { Management" } & \\
\end{array}$ & $\mathrm{A}++$ & 1204467 & 1141389 & 5,5 \\
\hline 3 & 3 & Group MC "Region" & $\mathrm{A}++$ & 870793 & 857634 & 1,5 \\
\hline 4 & 4 & $\begin{array}{l}\text { Asset Management Business } \\
\text { Company "OTKRITIE" }\end{array}$ & $\mathrm{A}++$ & 779802 & 713388 & 9,3 \\
\hline 5 & 6 & «Alfa-Capital» & $\mathrm{A}++$ & 668540 & 607507 & 10,0 \\
\hline 6 & 5 & $\begin{array}{lll}\text { Gazprombank } & - & \text { Asset } \\
\text { Management } & & \\
\end{array}$ & $\mathrm{A}++$ & 614729 & 635120 & $-3,2$ \\
\hline 7 & 8 & "Lider" & $\mathrm{A}++$ & 515207 & 511326 & 0,8 \\
\hline 8 & 7 & TKB Investment Partners & $\mathrm{A}++$ & 472036 & 582560 & $-19,0$ \\
\hline 9 & 10 & $\begin{array}{l}\text { "Progressive investment } \\
\text { ideas" }\end{array}$ & $\mathrm{A}+$ & 357964 & 338898 & 5,6 \\
\hline 10 & 9 & "TRANSFINGROUP" & $\mathrm{A}++$ & 354834 & 352471 & 0,1 \\
\hline 11 & 11 & "IQJ Asset Management" & - & 224299 & 223846 & 0,2 \\
\hline 12 & 12 & "Systema Capital" & $\mathrm{A}++$ & 175460 & 165704 & 5,9 \\
\hline 13 & 13 & "RSHB Asset Management" & - & 139938 & 123200 & 13,6 \\
\hline 14 & 14 & "Raffaizen Capital" & - & 106295 & 110443 & 10,5 \\
\hline 15 & 15 & "Ingosstrah-Investicii" & $\mathrm{A}++$ & 106295 & 106916 & $-0,6$ \\
\hline
\end{tabular}

Note: the table is compiled according to the Preliminary results III, 2020 and Preliminary results IV, 2020

At the end of 2020, the trust management market in Russia has grown significantly and reached 7.9 trillion rubles, mainly due to the growth of investments in various mutual funds (unit investment fund, mutual investment fund) (OPF, ZPF). However, growth has slowed slightly relative to 2019. VTB Capital Investment Management has taken the leading positions with 1.28 trillion. rubles of assets held in trust. The leader of 2019 - Sberbank Asset Management - lost its first place and is in second place with assets of 1.2 trillion. rubles. Key growth parameters are ensured by attracting funds from private investors, whose investments reach 200 billion rubles in total (Assets under management grow on retail, 2021). There is an increase in attention to closed-end mutual investment funds.

Another key feature of the market's functioning is the active growth in the number of investors. So, for example, in VTB Capital Asset Management alone, the number of private investors in 2020 increased by $45 \%$ and totals 92.6 thousand investors in total (Assets under management grow on retail, 2021).

In general, the Russian asset management and trust management market is characterized by active 
participation of state investors. Thus, one of the active participants in this market is Rosvoenipoteka, which is serviced by TKB Investment Partners. In addition, one of the drivers of the development of the trust management market is the introduction of income tax on deposits of individuals, as well as a decrease in rates on deposits, which reduces the attractiveness of this instrument and stimulates the search for more profitable investment instruments (Private investors choose bonds, foreign exchange strategies and mutual funds, 2020).

The largest growth in 2020 was shown by investments in mutual funds, especially industry funds (for example, high-tech companies, the consumer market, etc.) (Change of funds, 2021). The growth is observed mainly due to individual investors (and, accordingly, an increase in the share of individual trust management), military mortgage funds, financial investments in private investment funds. At the same time, activity in the segment of pension savings decreases, although their share remains significant. Nevertheless, the slowdown in growth indicates a decrease in the attractiveness of such an instrument, at least in the short term. The growth leader in Russia is the military mortgage and government investment ("Expert RA", 2021).

It should be noted that recently, due to the pandemic, there has been an increase and activity in the use of remote instruments and investment channels (Private investors choose bonds, foreign exchange strategies and mutual funds, 2020). In Russia, bond and quasi-deposit strategies, as well as instruments with dollar yield, are especially popular, but the market is developing around instruments with a low probability of risk.

In general, 2020 in the Russian market is characterized by an increase of 7\% (source: The bond market in 2020: booming despite the crisis, 2020). Moreover, during the crisis, a significant number of small and medium-sized enterprises entered the investment market, which consider trust management as one of the instruments in the overall investment portfolio. However, such trends were outlined back in 2019 and found their continuation in 2020, which manifested itself in an increase in the number of issuers. An obstacle for the development of such companies and their activation in the investment and trust management market is the low level of transparency of their activities, low ratings, quality and availability of reporting (both financial and non-financial).

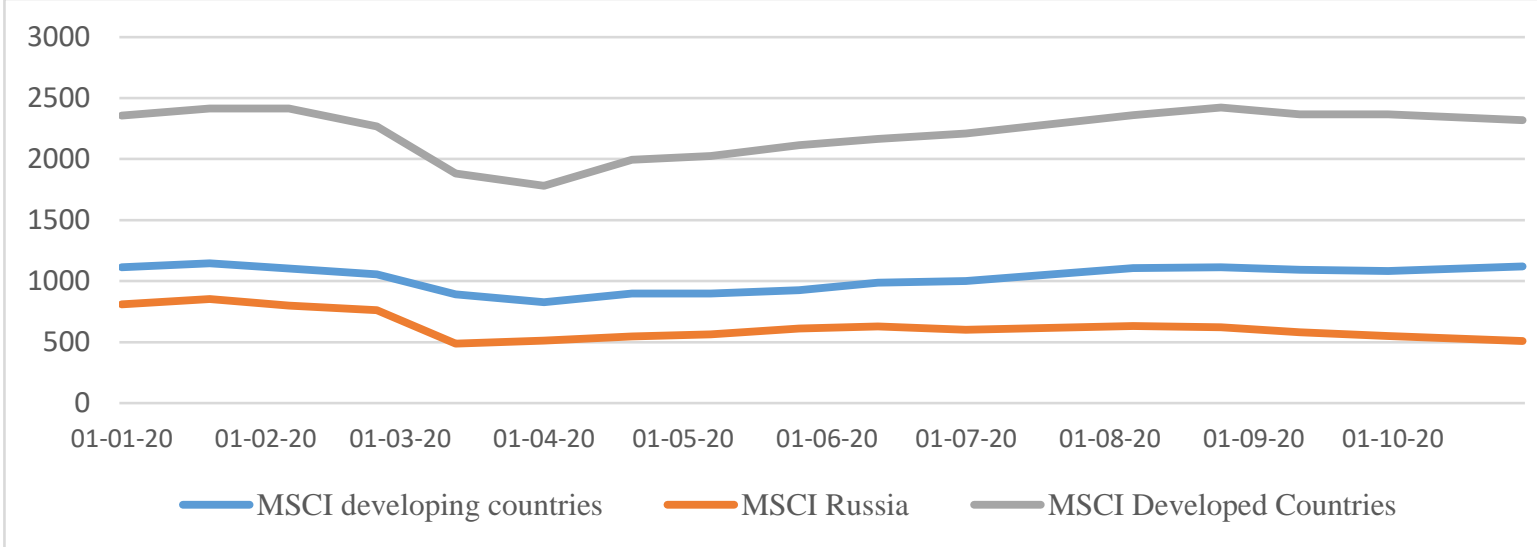

Fig. 1. Dynamics of MSCI indices, 2020

source: own calculations based on: The bond market in 2020: booming despite the crisis, 2020 
The pandemic and, accordingly, the crisis, which manifested itself, among other things, through the fall of key indices, became a serious problem for the development of the market (Fig. 1).

In general, the drop in indices is typical for all market segments and countries. However, the smallest drop was shown by developing countries with a total indicator of $31 \%$, while developed countries sank by $33 \%$. In Russia, the fall was $41 \%$, which was the result of both the global fall and the crisis in the oil market.

However, against this background, the popularity of less profitable and less risky instruments such as Federal Loan Bonds has increased. The profitability of these instruments increased over the same period, which is associated with the goal of withdrawing "extra" money from the market, to reduce the pressure on key players and key indices. The growth is especially noticeable in the segment of medium-term bonds (Fig. 2).

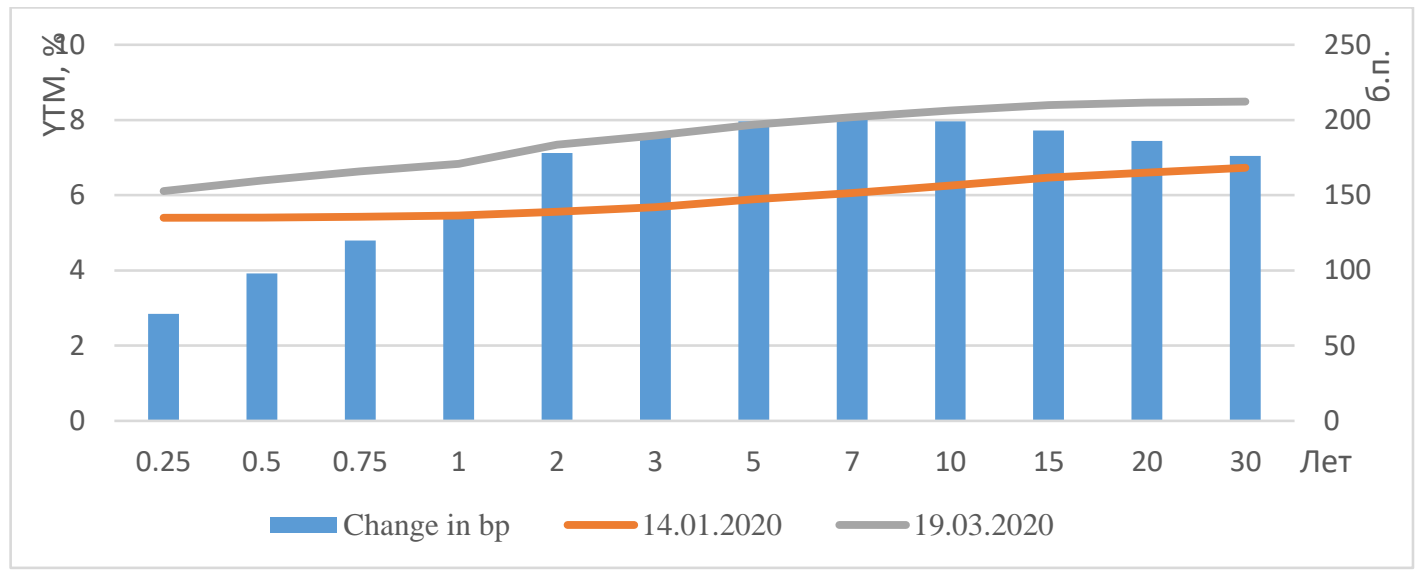

Fig. 2. Yield curve of OFZ, 2020

source: own calculations based on: The bond market in 2020: booming despite the crisis, 2020

At the same time, the relatively low level of Russia's integration into the world community contributed to a softer impact of the global crisis on the country. The high level of presence of state bodies in the market also limits the level of influence and evens out the market a little, although the market drawdown was quite significant (Table 2).

Table 2. Dynamics of GDP of individual countries of the world, 2020

\begin{tabular}{|l|c|c|}
\hline \multicolumn{1}{|c|}{ Country } & GDP growth rate, $\%$ & Credit rating \\
\hline China & $+3,2$ & $\mathrm{~A}+$ \\
\hline India & $-24,1$ & $\mathrm{BBB}-$ \\
\hline EC & $-15,0$ & $\mathrm{AAA}$ \\
\hline United Kingdom & $-21,7$ & $\mathrm{AA}$ \\
\hline Mexico & $-18,7$ & $\mathrm{BBB}+$ \\
\hline USA & $-9,1$ & $\mathrm{AAA}$ \\
\hline Germany & $-11,3$ & $\mathrm{AAA}$ \\
\hline Columbia & $-15,7$ & $\mathrm{BBB}$ \\
\hline Brasilia & $-11,4$ & $\mathrm{BB}$ \\
\hline
\end{tabular}




\begin{tabular}{|l|c|c|}
\hline Russia & $-8,5$ & BBB \\
\hline Turkey & $-9,9$ & BB- \\
\hline
\end{tabular}

Note: the table is compiled according to the Credit ratings, 2019; The bond market in 2020: booming despite the crisis, 2020

In general, we can note a fairly strong drop-in economic activity in the market, which is associated with the global crisis as well. In addition to a drop in GDP, in many countries we are also seeing a drop in interest rates, which is a criterion for an economic downturn and a desire to both attract free money to the market and stimulate economic activity (Fig. 3).

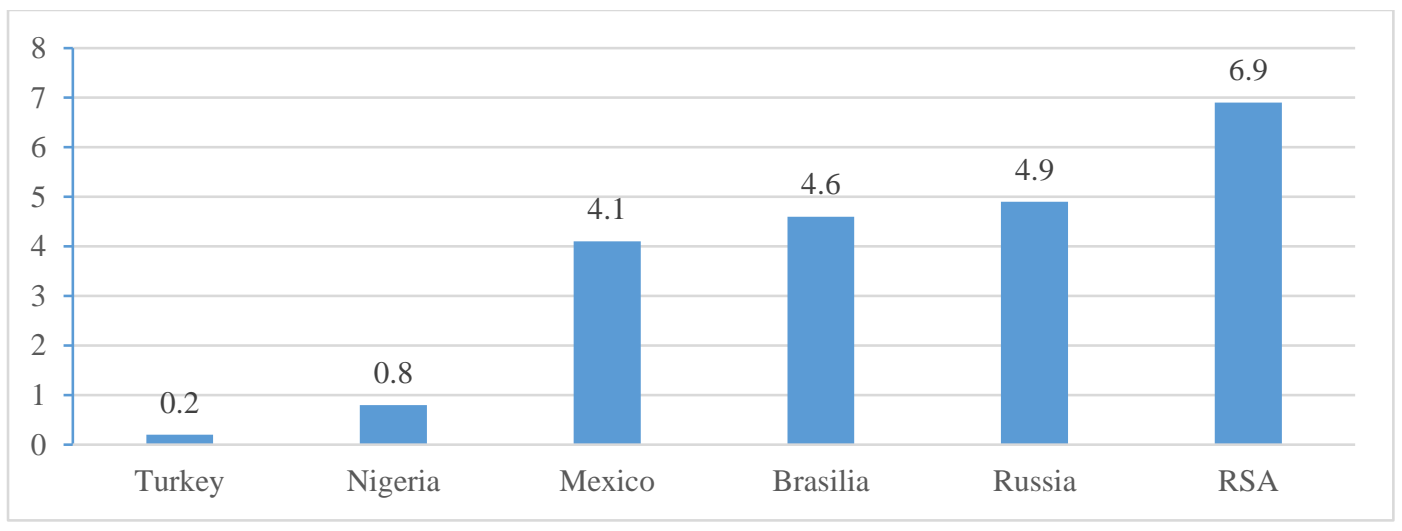

Fig. 3. The level of interest rates in hotel developing countries, 03.03.2020, \% source: own calculations based on: The bond market in 2020: booming despite the crisis, 2020

As you can see from the figure, the level of interest rates at the beginning of 2020 was quite high (relative to developed countries). However, in some countries (Turkey, Nigeria) the level is even lower, which reduces the overall investment attractiveness of the market.

It should be noted that by the end of 2020 , these same markets are showing a change in trends: for example, the attractiveness of Turkey has increased significantly, while the indicators of Russia and Mexico have dropped significantly (Fig. 4).

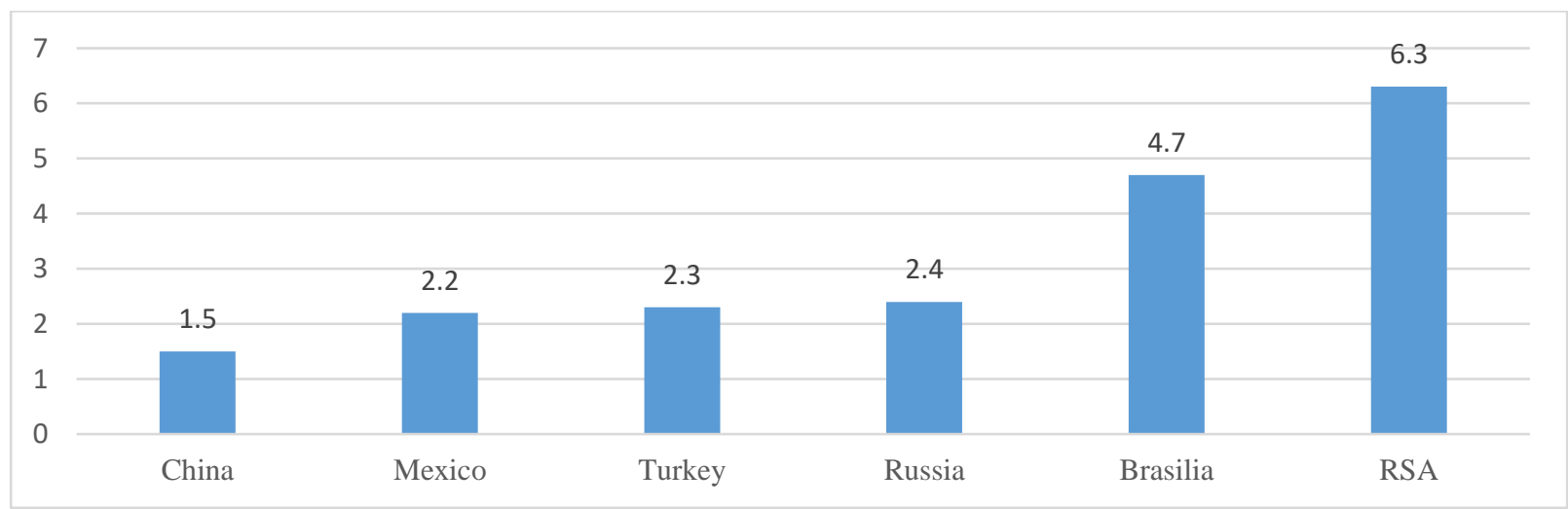

Fig. 4. The level of interest rates in hotel developing countries, $3.10 .2020, \%$ source: own calculations based on: The bond market in 2020: booming despite the crisis, 2020 
Such tendencies may be associated with the general participation of the country in investment flows, political and economic regime, participation of the state in economic processes and opportunities to guarantee investments, including those under trust. The Republic of South Africa has hardly changed its attractiveness, while Turkey has raised its rates from $0.2 \%$ to $2.2 \%$. This demonstrates an increase in the attractiveness of the market, although not enough, since the initial indicators are significantly lower than those of developing countries. In general, the yield on government bonds is at a rather low level and often does not even cover inflation, which does not contribute to the growth of the popularity of such investments. These investments are low risk and this determines the possibility of growth in this market segment. The desire of the governments of the countries to attract free money and accumulate it to cover the needs lead to an increase in interest rates, which is also determined by the desire of investors to abandon risky instruments in times of crisis. In general, in 2020, the volume of the market for government bonds (federal loans) in Russia increased, which just characterizes the demand for low-risk operations and investments (Fig. 5).

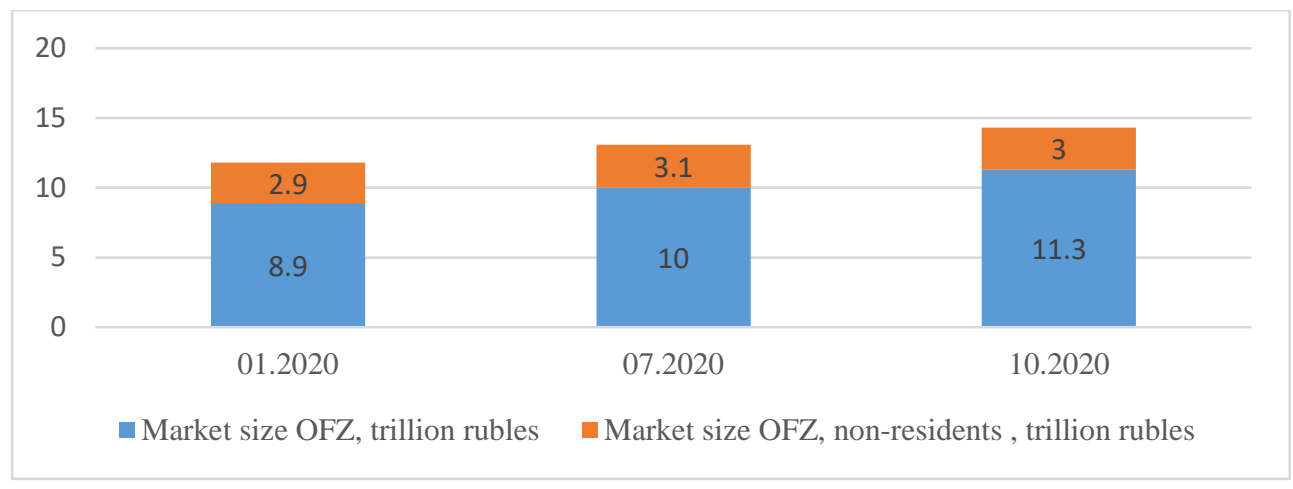

Fig. 5. Structure of the Russian federal loan bond market throughout 2020, trillion rubles source: own calculations based on: The bond market in 2020: booming despite the crisis, 2020

It should be noted that the share of non-residents in the market has significantly decreased, despite the slight change in quantitative indicators: only in the period from April to October, the share of non-residents decreased from $32 \%$ to $27 \%$. The decrease in the share of non-residents is primarily due to geopolitical risks, restrictions, sanctions of the European Union and a general increase in the number of OFZs in circulation. On the other hand, an increase in inflationary risks led to a decrease in the attractiveness of deposits and, as a result, to an increase in the attractiveness of the investment market, including the trust management market. Thus, in 2020, the number of clients on the Moscow Exchange exceeded 11 million. Moreover, there are more than 1 million active clients, and the average monthly turnover indicators showed an increase of $33 \%$ in the market as a whole.

The increase in activity led to the active growth of Individual Investment Accounts (IIA) (including those under trust) (Fig. 6). 


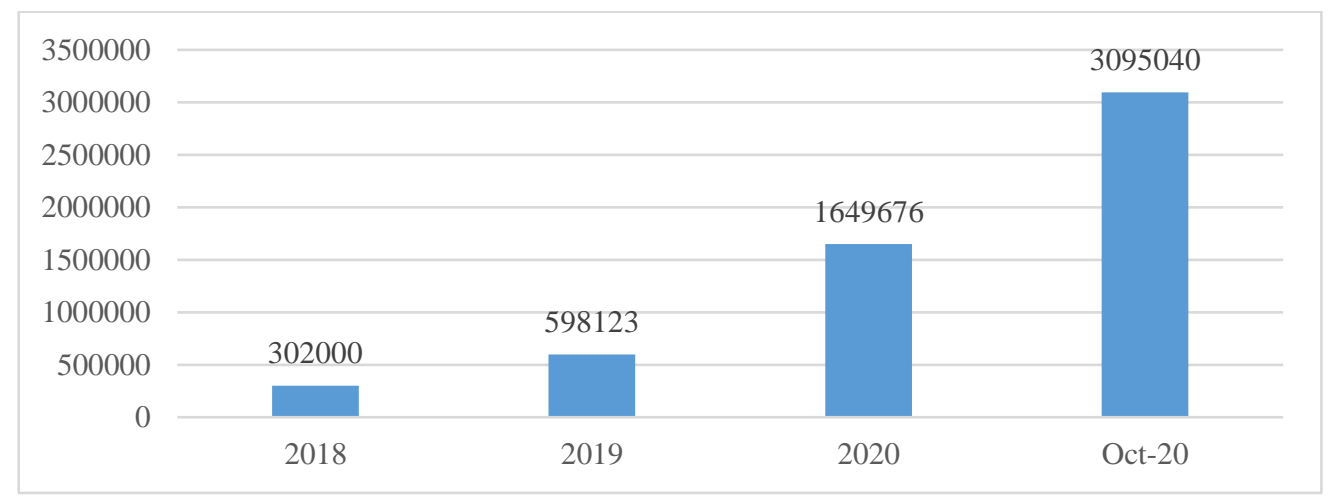

Fig. 6. Number of individual investment accounts, at the beginning of the year, units. source: own calculations based on: The bond market in 2020: booming despite the crisis, 2020

As you can see, in just two incomplete years, the number of individual investment accounts has increased more than 10 times, which is due to the reasons described above. In general, such trends have led to an increase in the bond market and an increase in the amount of financial resources under trust (Fig. 7).

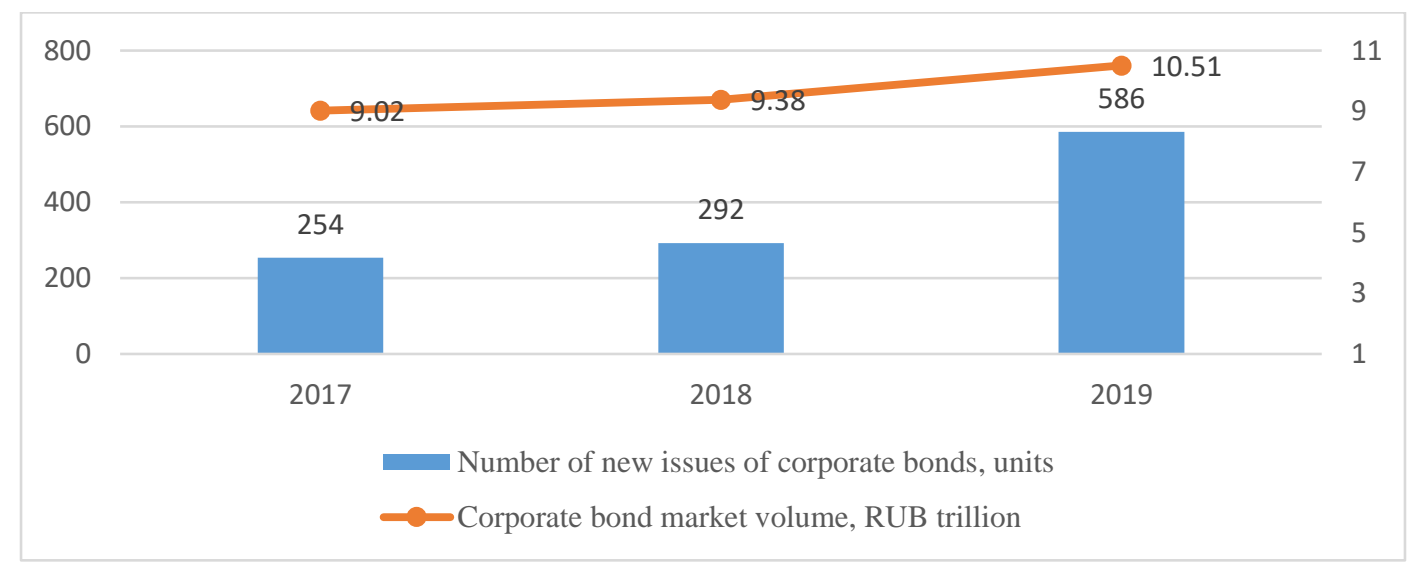

Fig.7. Dynamics of development of the bond market in Russia, 2017-2019.

It is worth noting that market fluctuations were less reflected in large companies: bonds of the first and second tier companies are characterized by a smaller spread, which can actually lead to zero potential profitability. The largest tier 1 companies (blue chips) may have a spread of less than $1 \%$ (Second-tier stocks - what are they? Where to find and how to buy 2nd tier stocks? 2020). In general, during the analyzed period, there is a decrease in the spread for the first echelon shares, where the profitability was practically covered by the difference in value, which is primarily determined by the low level of riskiness of such securities. Securities with AAA - AA- indicators show very low changes in values and, accordingly, a very low spread. At the same time, securities with $A+-B B B$ indicators have a sufficient level of stability and a sufficient level of profitability to attract closer attention of investors in this situation. Similar trends can be noted for these securities in terms of YTM indicators (Yield to maturity, yield to maturity) (Fig. 8). 


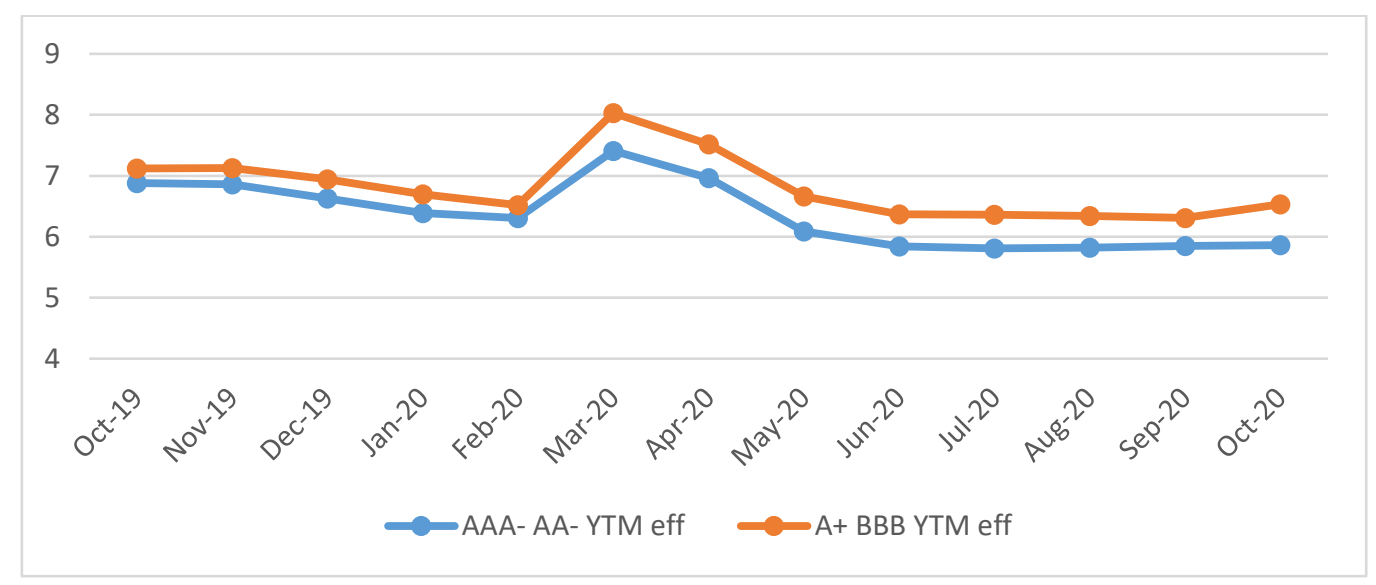

Fig. 8. Yield of bonds to maturity, 2019-2020

As you can see, bonds with a lower credit rating have a higher yield. The dynamics of bond yields declined at a higher rate than for high-yield securities. In contrast, the yields on second-tier securities showed higher stability (especially for securities with BBB and below indicators). Such trends are primarily determined by an increase in the number of individual investors (individuals) in the market (Table 3).

Table 3. Structure of the Russian bond market, \%, 2020

\begin{tabular}{|l|c|c|}
\hline & Primary market & Secondary market \\
\hline Trust management & 25 & 19 \\
\hline Banks and brokers & 38 & 41 \\
\hline Non-residents & 4 & 16 \\
\hline Legal entities & 16 & 14 \\
\hline Individuals & 17 & 11 \\
\hline
\end{tabular}

Note: the table is compiled according to the bond market in 2020: booming despite the crisis, 2020

As you can see, the participation of individuals, represented both in the segment of individuals themselves and in the structure of trust management, constitutes a significant part of the market. At the same time, these market participants are quite cautious and, in case of loss of capital, can leave the market rather quickly. This is especially true for the primary market, since market participants must understand that higher returns are characteristic only for securities with a higher level of risk. Individuals-investors in this market have a low level of financial literacy, not channeling their resources into trust funds and into the hands of more literate market participants. A specific feature of the Russian market is the active participation of unrated issuers, which further complicates the ability to forecast market development (Fig. 9). 


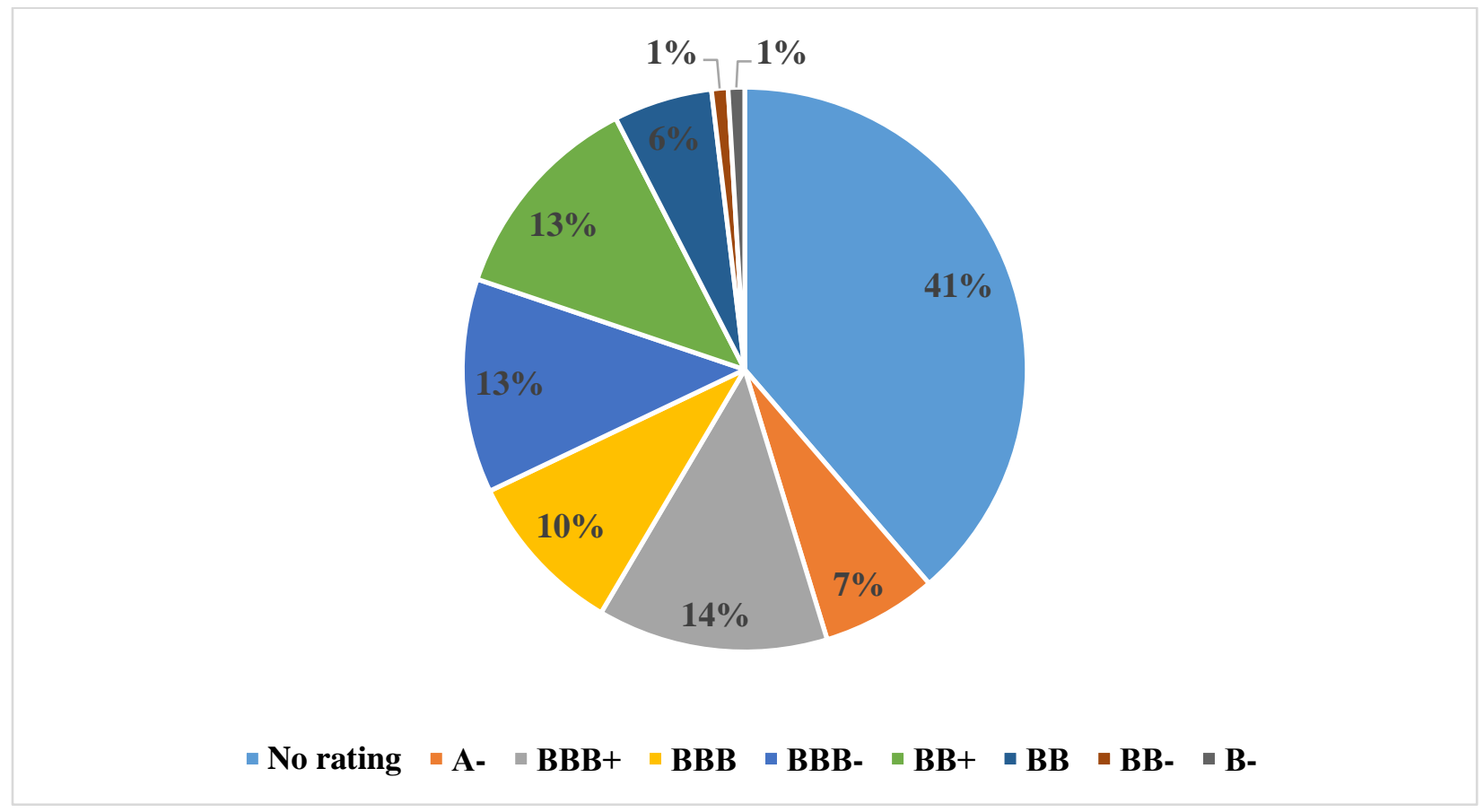

Fig. 9. Structure of the Russian high-yield bond market, \%, 2020

source: own calculations based on: The bond market in 2020: booming despite the crisis, 2020

This situation can lead to underestimation of unrated companies and securities. On the other hand, this contributes to an increase in confidence in issuers with low ratings (BBB and less), for which, however, the rating is determined. In general, $\mathrm{BBB}+$ securities are defined as the minimum investment grade, which determines listing access and, in principle, listing eligibility. In this case, there is a mixture of securities, both unrated and rated $\mathrm{BB}$ and $\mathrm{BBB}$ in the segment of high yield bonds, which in turn leads to a blurring of the boundaries between the segments of securities and issuers of the first and second echelons.

In general, the situation is quite typical for all developing countries. The peculiarities of the Russian securities market are: active participation of the state in the processes of market trading, a large number of government securities on the market and a relatively low level of involvement in global processes. Opportunities for solving key market problems include increasing the general level of financial literacy, increasing information transparency of the market, introducing a workflow that would comply with international standards and corporate governance standards, increasing the rating coverage of issuers, increasing the number of reporting and its transparency (for example, international financial and accounting standards).

\section{CONCLUSION}

In general, it should be noted that the trust management market is only in the process of formation, although the services themselves have a long history of development. They are most often viewed as part of the overall market for banking or insurance services. At the present stage, there is a selection of a separate market segment, 
determination of the place of trust services in the structure of banking services, identification of regional characteristics in the structure of the global market.

We can note that the market of Eastern Europe and Russia in particular is at the stage of its formation. The trust management service is relatively new and has not yet gained popularity as other banking services. The market is relatively small, but its development is quite dynamic. The key prerequisites for the development of the market are: the relative closeness of the market, government regulation, a decrease in the attractiveness of other banking or financial instruments, and an increase in the general welfare of investors. In general, the study of key features and new trends in the development of asset trust management services is of significant scientific and practical interest.

\section{Conflict of interests}

The authors declare no conflict of interest.

\section{References}

Angelov, A., Vytev, Z., Marinov, M., Radukanov, S. (2012). Graphical analysis techniques of market trends. Scientific Research Almanac, DA Tsenov Academy of Economics, Svishtov, Vol. 16, pp.1-12

Asaul A.N., Abajev H.S., Molchanov Ju.A. (2007). Management, operation and development of property complexes. SPb.: Humanistics. URL: http://www.aup.ru/books/m7/2_1_5.htm

Assets under management grow on retail. (2021). URL:https://raexpert.ru/researches/publications/kommersant jan26_2021/

Change of funds. (2021). URL: https://www.kommersant.ru/doc/4660993

Credit ratings of countries of the world: S\&P, Fitch and Moody’s. (2019). URL: https://tyulyagin.ru/ratings/kreditnyerejtingi-stran-mira-sp-fitch-imoodys.html\#: :text=\%D0\%9A\%D1\%80\%D0\%B5\%D0\%B4\%D0\%B8\%D1\%82\%D0\%BD\%D1\%8B\%D0\%B5 $\% 20 \% \mathrm{D} 1 \% 80 \% \mathrm{D} 0 \% \mathrm{~B} 5 \% \mathrm{D} 0 \% \mathrm{~B} 9 \% \mathrm{D} 1 \% 82 \% \mathrm{D} 0 \% \mathrm{~B} 8 \% \mathrm{D} 0 \% \mathrm{BD} \% \mathrm{D} 0 \% \mathrm{~B} 3 \% \mathrm{D} 0 \% \mathrm{~B} 8 \% 20 \% \mathrm{D} 1 \% 81 \% \mathrm{D} 1 \% 82 \% \mathrm{D} 1$ $\% 80 \% \mathrm{D} 0 \% \mathrm{~B} 0 \% \mathrm{D} 0 \% \mathrm{BD} \% 20 \% \mathrm{D} 0 \% \mathrm{BC} \% \mathrm{D} 0 \% \mathrm{~B} 8 \% \mathrm{D} 1 \% 80 \% \mathrm{D} 0 \% \mathrm{~B} 0 \% 20 \% \mathrm{D} 0 \% \mathrm{~B} 0 \% \mathrm{D} 0 \% \mathrm{~B} 3 \% \mathrm{D} 0 \% \mathrm{~B} 5 \% \mathrm{D} 0 \% \mathrm{~B}$ D\%D1\%82\%D1\%81\%D1\%82\%D0\%B2\%20S\&P,\%20Fitch\%20\%D0\%B8,\%20\%20

"Expert RA": the trust management and collective investment market grew by 5.4\%. (2020). URL: https://raexpert.ru/researches/publications/banki_aug18_2020/

Fedulova D.V. (2010). The civil legal essence of trust management. Bulletin of Tomsk State University. №1. C. 113-116. URL: https://cyberleninka.ru/article/n/grazhdansko-pravovaya-suschnost-doveritelnogo-upravleniya/viewer

Kovalevich A.E. (2012). Trust management: essence and content. Bulletin of the Belarusian State Economic University. № 4. C. 73-79.

Labunska Sv., Petrova M., Prokopishyna O. (2017). Asset and cost management for innovation activity, "Economic Annals - XXI", Vol. 165, ISSUE 5-6, Pages: 13-18. DOI: https://doi.org/10.21003/ea.V165-03

Loistl O., Petrag R. (2003). Asset Management Standards. DOI:10.1057/9781403946058

Marinov, M. (2012). Researching variations in the market trend by using indicators for technical analysis. "Scientific research" Almanac, vol. 18, pp. 187-204

Mazajeva A.V. (2017). Trust: the experience of civil law countries. Journal of Foreign Law and Comparative Jurisprudence. №1. URL: https://cyberleninka.ru/article/n/doveritelnoe-upravlenie-i-trast-opyt-strankontinentalnogo-prava/viewer 
Milinov, V. (2012). On evolution and the new challenges facing bank marketing in the aftermath of the financial crisis. "Scientific research" Almanac, vol. 18, pp. 167-186

Petrova, M., Radukanov, S. (2021). Expenditures for innovations and foreign direct investments in Bulgaria - regional aspects, features and trends. SHS Web of Conf., 10th Annual International Conference "Schumpeterian Readings" (ICSR 2021), Virtual and Perm, Russia, April 7 and April 15-16, 2021. Volume 116, https://doi.org/10.1051/shsconf/202111600050

Preliminary results of the trust management market in the III quarter of 2020 . URL: https://raexpert.ru/researches/ua/du 3q_2020pre/

Preliminary results of the trust management market in the IV quarter of 2020. (2020). URL: https://raexpert.ru/researches/ua/du_4q_2020pre/

Private investors choose bonds, foreign exchange strategies and mutual funds. (2020). URL: https://raexpert.ru/researches/publications/vedomosti_aug18_2020/

Puchkina E.S., Rindina I.V., Morusova O.G. (2016) Otsenka i sovershenstvovanije dejatelnosti bankov v sphere doveritelnogo upravlenija sredstvami chastnih investorov. Finansi $i$ kredit. №15 (687). C. 2-19. URL: https://cyberleninka.ru/article/n/otsenka-i-sovershenstvovanie-deyatelnosti-bankov-v-sfere-doveritelnogoupravleniya-sredstvami-chastnyh-investorov

Radukanov, S. (2012). Trends in the development of profitability and risk profile of the banking sector in our country. "Scientific research" Almanac, vol. 18, pp.243-253

Second-tier stocks - what are they? Where to find and how to buy 2nd tier stocks? (2020). URL: https://internetboss.ru/akcii-vtorogo-eshelona/

Smirnov I. (2020). Trust. URL: https://myfin.by/wiki/term/doveritelnoe-upravlenie

The bond market in 2020: booming despite the crisis. (2020). URL: https://raexpert.ru/researches/ua/bond2020/

Vorotilov A. (2013). Subtlety of control. URL: https://forbes.kz/finances/markets/tonkost_upravleniya/

Woodhouse J. (2003). Asset Management: concepts \& practice. https://www.researchgate.net/publication/ 228905772_Asset_Management_concepts_practices

Woodhouse J. (2018). Value in Asset Management. Infrastructure Asset Management. 6(2):1-25. DOI:10.1680/jinam.17.00040

\section{About the author}

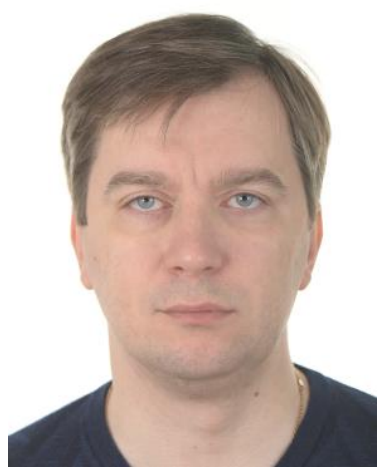

\section{Stanislav PERMINOV}

Current position: PhD Students, ISMA; Russia

University studies: London Business School - Corporate Finance Modular Programme - 2006-2007; Moscow Institute of Economics, Management and Law - Economist in Finances and Loans - 1997 - 1999; Moscow State Technical University in honor of N.E. Bauman - Mechanical Engineer/ Researcher with specialization in Machine Dynamics and Strength - 1988 1994

Scientific interest: trust management, banking management

ORCID ID: https://orcid.org/0000-0002-9353-8365 